\title{
Preeclampsia and eclampsia incidence in the eastern anatolia region of Turkey: the effects of high altitude
}

\section{Türkiye'nin Doğu Anadolu Bölgesinde preklampsi ve eklampsi insidansı: Yüksek rakımın etkileri}

\author{
Yakup Kumtepe ${ }^{1}$, Onur Dündar ${ }^{2}$, Kadir Çetinkaya ${ }^{3}$, Metin İngeç ${ }^{l}$ \\ 'Department of Obstetrics and Gynecology, Faculty of Medicine, Atatürk University, Erzurum, Turkey \\ ${ }^{2}$ Department of Obstetrics and Gynecology, Trabzon Women's Hospital, Trabzon, Turkey \\ ${ }^{3}$ Department of Obstetrics and Gynecology, Ankara Oncology Education and Research Hospital, Ankara, Turkey
}

\section{Abstract}

Objective: Hypertensive disorders of pregnancy remain a leading cause of maternal and perinatal mortality and morbidity. The purpose of this study was to determine the distribution map related to pregnancy toxicosis of provinces in our region and the effects of altitude on hemolysis, elevated liver enzymes, low platelets (HELLP) syndrome and eclampsia.

Materials and Methods: Patients who were admitted to Atatürk University, Obstetrics and Gynecology Department with preeclampsia, eclampsia and a diagnosis of HELLP syndrome for the 5 years between1998-2002 were chosen. The birth rate was obtained from the health directorate of provinces in our area during the same period. Provinces were divided into two groups by altitude: less than and more than $1500 \mathrm{~m}$ above sea level.

Results: The rates of HELLP syndrome and eclampsia diagnoses were 1.4 per 10.000 patients living above $1500 \mathrm{~m}$ altitude. However, this rate was 0.96 per 10.000 patients living below $1500 \mathrm{~m}$ altitude $(\mathrm{p}<$ 0.01 ). The highest rate of eclampsia and HELLP syndrome was seen in the Ardahan province, in 36 patients per 10,000 births, whereas the lowest rate was seen in the Iğdır province, 9.9 patients per 10,000 births.

Conclusion: Altitude contributes to occurrence of HELLP syndrome and eclampsia. Since the rate of pregnancy related hypertension is higher at high altitude, it is vital that these patients should be diagnosed during the early stages of the diseases in order to decrease complications.

(J Turkish-German Gynecol Assoc 2011; 12: 26-30)

Key words: Preeclampsia, eclampsia, HELLP syndrome, high altitude Received: 21 November, 2010

Accepted: 29 January, 2011

\section{Introduction}

There is a prominent increase in all arterial flow (consequently, uterine artery blood flow), a decrease in the vasoconstrictor response of the vascular system, and an increase in the vasodilator response during normal pregnancy (1). The results of animal-based studies have shown that there is a decreased response to alpha-adrenergic stimulation of the vascular system and an increase in endothelium-dependent
Özet

Amaç: Gebeliğin hipertansif hastalıkları maternal ve perinatal mortalite ve morbiditenin önde gelen sebebi olmaya devam etmektedir. Bu çalışmanın amacı, bölgemizdeki illere gore gebelik toksikozu dağılım haritası çıkarmak ve hemoliz, yükselmiş karaciğer enzimleri, düşük platelet (HELLP) sendromu ve eklampsi üzerine yüksek rakımın etkilerini belirlemektir.

Gereç ve Yöntemler: Atatürk Üniversitesi, Kadın Hastalıkları ve Doğum bölümüne 1998-2002 yılları arasında 5 yıllık bir dönemde preeklampsi, eklampsi ve HELLP tanısı ile başvuran hastalar seçildi. Aynı dönemde, il sağlık müdürlüklerinden doğum hızları temin edildi. Deniz seviyesine göre $1500 \mathrm{~m}$ altında ve üstünde olmak üzere iller iki gruba ayrild.

Bulgular: HELLP sendromu ve eklampsi tanıları $1500 \mathrm{~m}$ üzerinde 10.000 doğumda 1.4 izlenirken, $1500 \mathrm{~m}$ altında 0.96 izlenmiștir $(\mathrm{p}<0.01)$. En yüksek HELLP sendromu ve eklampsi Ardahan ilinde 10.000 doğumda 36 izlenirken, en düşük Iğdır ilinde 10.000 'de 9.9 olarak izlenmiştir.

Sonuç: Rakım, HELLP sendromu ve eklampsi oluşumunda rol alır. Yüksek rakımda yaşayanlarda gebelik ile ilişkili hipertansif hastalıkların daha yüksek oranda izlendiği için komplikasyonların azaltılabilmesinde hastalığın erken dönemlerinde tanı alması hayati önem taşımaktadır.

(J Turkish-German Gynecol Assoc 2011; 12: 26-30)

Anahtar kelimeler: Preeklampsi, eklampsi, HELLP sendromu, yüksek rakım

Geliş Tarihi: 21 Kasım 2010

Kabul Tarihi: 29 Ocak 2011

vasodilatation caused by increased basal and stimulated endothelium-derived nitric oxide $(2,3)$. However, in pregnancies developing preeclampsia at a later stage, there is evidence of vasoconstriction, increased vascular tone, platelet aggregation, and an alteration in the thromboxane-to-prostacyclin ratio (4). Maternal and fetal morbidity and mortality rates increase in hypertensive disorders of pregnancy (5).

Preeclampsia is seen in $2-7 \%$ of all pregnancies, and its frequency is higher in primigravid than in multigravid women 
$(6,7)$. It is also more frequently seen in women carrying more than one fetus, older women, women with genetic factors, hyperlipidemia, thrombophilia, obesity, and diabetes mellitus, women experiencing preeclampsia during a previous pregnancy, and those living at high altitudes (8-13).

Preeclampsia is a multisystem disease that affects both mother and fetus. There is a progressive loss of musculoelastic tissue on spiral arteries in normal placental development, because extravillous cytotrophoblasts migrate up the spiral arteries and cause an erosion of the vascular smooth-muscle layer of the maternal spiral arteries, resulting in a loss of vasoactivity, subsequent dilatation, and a decrease in uteroplacental vascular resistance (9). Thus, uterine blood flow increases approximately $25 \%$ throughout the first trimester. However, in women living at high altitude, hypoxia inhibits the transition of the trophoblast from a resting, proliferative phenotype to an invasive phenotype and, hence, may inhibit arterial remodeling (10). As a result, maternal arterial oxygen pressure and uterine blood flow decrease at high altitude (11). This physiological dilatation does not occur in patients prone to preeclampsia, because placental trophoblastic cells do not wrap up spiral arteries, therefore spiral arteries are tightened and shortened, and uteroplacental blood flow decreases (14). Because of increased hypoxia, living at high altitude causes important health problems. Studies have revealed that intrauterine growth restriction (IUGR), preterm labor, abruptio placentae, and preeclampsia increase with increasing altitude (12, 15). Hemolysis, elevated liver enzymes, and low platelet count (HELLP) syndrome were first reported by Weinstein (16) in 1982, and immediate termination of pregnancy was proposed because of high maternal and perinatal mortality rates. However, Weinstein did not announce a cut off value of parameters. The cut off values for HELLP syndrome that are used now were defined by Sibai (17) in 1990. Eclampsia and preeclampsia are serious problems and account for $10 \%$ of maternal mortality worldwide (18). HELLP syndrome can be considered a serious variant of preeclampsia, and it occurs in $0.90 \%$ of all pregnancies and in $10-20 \%$ of cases with severe preeclampisa (19). Associated with liver, kidney, and serious coagulation disorders, HELLP syndrome carries significant maternal and perinatal risk, because disseminated intravascular coagulation (DIC), abruptio placenta, acute renal problems, pulmonary edema, subcapsular liver hematoma, and retinal detachment are frequently seen in HELLP syndrome (4). The purpose of the present study was to determine the rates of HELLP syndrome, preeclampsia, and eclampsia in association with altitude.

\section{Material and Methods}

The study was carried out retrospectively by medical record examination, in patients with preeclampsia-eclampsia who had been admitted to Atatürk University, Faculty of Medicine, Department of Obstetrics and Gynecology during the period between 1998-2002. The total number of births that took place in the Eastern Anatolia Region of Turkey during this 5-yearperiod was obtained from the Health Directorate of Provinces. During the same time, the numbers of births and patients with preeclampsia, eclampsia, and HELLP syndrome were recorded. Patients from the city of Erzurum and its provinces and neighboring cities were divided into 2 groups according to altitude (Table 1). Group 1, patients living at over $1500 \mathrm{~m}$, included Karaçoban (1945 m), Köprüköy (1747 m), Tortum (1772 m), Pasinler (1660 m), Aşkale (1700 m), Narman (1830 m), Çat (1920 m), Karayazı (2260 m), and Hınıs (1795 m) provinces and Bayburt (1680 m), Ağrı (1738 m), Kars (1859 m), Ardahan (1929 m), Erzurum (1864 m) city centers. Group 2, patients living at under $1500 \mathrm{~m}$, included Ispir (1222 m), Olur (1300 m), Uzundere $(1300 \mathrm{~m})$, and Oltu $(1229 \mathrm{~m})$ provinces and Artvin (628 m), Iğdır (758 m), Bingöl (1177 m), Erzincan (1058 m), and Muş (1224 m) city centers.

Preeclampsia was defined in accordance with the criteria of the American College of Obstetrics and Gynecology (20). Mild preeclampsia was diagnosed if systolic blood pressure was $\geq 140 \mathrm{mmHg}$, diastolic blood pressure was $\geq 90 \mathrm{mmHg}$, and proteinurea was $\geq 0.3 \mathrm{~g} / \mathrm{L}$ in a 24 -hour urine sample. Severe preeclampsia was diagnosed when one of the following criteria was present: (1) blood pressure $\geq 160 \mathrm{mmHg}$ systolic or $\geq 110$ mmHg diastolic on two occasions at least 6 hours apart with the patient on bed rest, (2) proteinurea $\geq 5 \mathrm{~g}$ in a 24-hour urine collection or $\geq 3+$ on dipstick in at least two random clean-catch samples at least 4 hours apart, or (3) eclampsia. Eclampsia was diagnosed if the patient who had previously been diagnosed with preeclampsia had convulsions, once other causes of convulsions had been ruled out.

To determine mean hypertension, mean arterial pressure $(\mathrm{MAP})$ was calculated $[\mathrm{MAP}=(2 \times$ diastolic pressure + systolic pressure)/3] after admission and before treatment for each patient. HELLP syndrome was diagnosed according to strict Sibai criteria (17) as follows:

Table 1. Altitudes of provinces and districts

\begin{tabular}{|c|c|c|c|}
\hline \multicolumn{2}{|c|}{ Group 1 (>1500 m) } & \multicolumn{2}{|c|}{ Group $2(<1500 \mathrm{~m})$} \\
\hline Province/district & $\begin{array}{l}\text { Altitude } \\
\text { (m) }\end{array}$ & Province/district & $\begin{array}{c}\text { Altitude } \\
\text { (m) }\end{array}$ \\
\hline Erzurum (Karaçoban) & 1945 & Artvin & 628 \\
\hline Erzurum (Köprüköy) & 1747 & Iğdır & 758 \\
\hline Erzurum (Tortum) & 1772 & Bingöl & 1177 \\
\hline Bayburt & 1680 & Erzincan & 1058 \\
\hline Ağn & 1738 & Erzurum (İspir) & 1222 \\
\hline Erzurum (Aşkale) & 1700 & Erzurum (Uzundere) & 1300 \\
\hline Erzurum (Narman) & 1830 & Erzurum (Olur) & 1300 \\
\hline Erzurum (Hınıs) & 1795 & Muş & 1224 \\
\hline Kars & 1859 & Erzurum (Oltu) & 1229 \\
\hline Ardahan & 1929 & & \\
\hline Erzurum (Centre) & 1864 & & \\
\hline Erzurum (Çat) & 1920 & & \\
\hline Erzurum (Karayazı) & 2260 & & \\
\hline Mean & $.2 \pm 150.7$ & Mean & $6 \pm 243.5$ \\
\hline
\end{tabular}


1. Hemolysis: characteristic appearance of peripheral blood smear and serum $\mathrm{LDH} \geq 600 \mathrm{U} / \mathrm{L}$ or serum total bilirubin $\geq 1.2 \mathrm{mg} / \mathrm{dL}$.

2. Elevated liver enzymes: AST concentration $\geq 70 \mathrm{U} / \mathrm{L}$.

3. Low platelet count: $<100,000$ cells $/ \mu \mathrm{L}$.

The patients who had all these 3 indications and those who had 1 and/or 2 of these indications were categorized as complete and partial HELLP syndrome.

Our database included only the patients with HELLP syndrome and eclampsia. Maternal age, gravidity, parity, and gestational age were recorded in patients with HELLP syndrome and eclampsia in both groups. Numbers of Cesarean births were obtained for an evaluation of birth position for both groups. Fetal or live birth numbers and birth weights were recorded to evaluate the fetal situation. Platelet count as well as aspartate aminotransferase (AST), alanine aminotransferase (ALT), lactate dehydrogenase (LDH), bilirubin, and uric acid levels in blood were analyzed to evaluate the incidence rate of HELLP syndrome.

Statistical analyses were performed using the Minitab Packed program, and differences between groups were determined by the Mann Whitney U test. Data are given as mean \pm standard deviation.

\section{Results}

The total number of births was 114,819 in group 1 and 81,454 births in group 2 over the 5 -year period (1998-2002) (Table 2). In group1, there was a total of 164 diagnosed patients (HELLP+ eclampsia) and 75 of these had eclampsia (54 patients accompanied by HELLP syndrome and 21 patients accompanied by preeclampsia). In group 2 , there was a total of 78 diagnosed patients (HELLP+eclampsia) and 45 had eclampsia (33 patients accompanied by HELLP syndrome and 12 patients accompanied by preeclampsia) (Table 3).

There were no differences in the two groups for age, gravidity, parity, gestational age, normal birth rate, and fetal weight. Cesarean births in groups 1 and 2 were 94 (57\%) and 44 (56\%), respectively. Platelet count and concentrations of AST and LDH were $87.648 \pm 109.970 / \mu \mathrm{l}, 172 \pm 237 \mathrm{IU} / \mathrm{L}$, and $1366 \pm 1293$ IU/L, respectively in patients in group 1 ( $>1500 \mathrm{~m}$ altitude) and $96.347 \pm 109.970 / \mu \mathrm{l}, 146 \pm 109 \mathrm{IU} / \mathrm{L}$, and $1208 \pm 755 \mathrm{IU} / \mathrm{L}$, respectively in patients in group $2(<1500 \mathrm{~m}$ altitude) (Table 4$)$.

During this study, 8100 births occurred in our clinic, and in 582 cases preeclampsia and eclampsia were diagnosed (7.2\%). A total of 242 patients were evaluated for HELLP syndrome and eclampsia, and 10 patients were excluded from the study because of a high level of liver enzymes suggesting viral hepatitis in 4 patients, DIC owing to an intrauterine dead fetus in 3 patients, and hepatotoxic medicine usage in 3 patients. In group 1, of 144 patients who were suspected of having HELLP syndrome, there were 69 (48\%) with complete and 75 (52\%) with partial HELLP syndrome. Of 75 patients with partial HELLP syndrome, AST level was $>70 \mathrm{IU} / \mathrm{L}$ in 38 patients, AST level and platelet count were $>70 \mathrm{IU} / \mathrm{L}$ and $<100,000 / \mu \mathrm{l}$ in 19 patients, and the platelet count was $<100,000 / \mu$ l in 17 patients. When parity and maternal age in patients with complete and partial HELLP
Table 2. Birth numbers in subject populations

\begin{tabular}{|c|c|c|c|c|c|c|}
\hline \multirow{2}{*}{$\begin{array}{l}\text { Groups } \\
\text { Group } 1 \text { (altitude }>1500 \mathrm{~m} \text { ) }\end{array}$} & \multicolumn{6}{|c|}{ Year } \\
\hline & 1998 & 1999 & 2000 & 2001 & 2002 & Total \\
\hline Ağn & 5746 & 7984 & 7885 & 7853 & 7950 & 37418 \\
\hline Ardahan & 210 & 1082 & 1532 & 974 & 1071 & 4869 \\
\hline Bayburt & 1215 & 1563 & 1308 & 1197 & 1092 & 6375 \\
\hline Erzurum $^{+}$ & 15200 & 13813 & 14689 & 12969 & 7517 & 50108 \\
\hline Kars & 3028 & 2896 & 2600 & 3208 & 4317 & 16049 \\
\hline \multicolumn{6}{|l|}{ Grand Total } & 114819 \\
\hline \multicolumn{7}{|l|}{ Group 2 (altitude $<1500 \mathrm{~m}$ ) } \\
\hline Artvin & 1816 & 1749 & 1775 & 1339 & 1377 & 8056 \\
\hline Bingöl & 2634 & 2508 & 2550 & 2561 & 1921 & 12174 \\
\hline Erzincan & 4363 & 5658 & 6009 & 5039 & 3521 & 24590 \\
\hline Iğdır & 2118 & 1739 & 1093 & 1369 & 1547 & 7866 \\
\hline Muş & 2234 & 3050 & 3309 & 3479 & 2616 & 14688 \\
\hline Erzurum ${ }^{++}$ & 2852 & 2951 & 2742 & 2789 & 2746 & 14080 \\
\hline \multicolumn{6}{|l|}{ Grand Total } & 81454 \\
\hline \multicolumn{7}{|c|}{$\begin{array}{l}\text { +Erzurum centre and Aşkale, Hınıs, Çat, Karayazı, Karaçoban, Horasan, Pasinler, Köprü- } \\
\text { köy, Tortum, and Şenkaya districts. } \\
{ }^{++} \text {Oltu, Olur, İspir, and Uzundere districts }\end{array}$} \\
\hline
\end{tabular}

Table 3. Patients with HELLP syndrome and eclampsia

\begin{tabular}{|l|c|c|}
\hline Diagnosis & $\begin{array}{c}\text { Group 1 } \\
\text { (altitude } \mathbf{1 5 0 0} \mathbf{~ m} \text { ) }\end{array}$ & $\begin{array}{c}\text { Group 2 } \\
\text { (altitude < 1500 m) }\end{array}$ \\
\hline Total patients & 164 & 78 \\
\hline Total HELLP & 143 & 66 \\
\hline Eclampsia & 75 & 45 \\
\hline $\begin{array}{l}\text { Eclampsia } \\
\text { accompanied by HELLP }\end{array}$ & 54 & 33 \\
\hline
\end{tabular}

syndrome were considered in group 1, maternal age and parity in patients with complete and partial HELLP syndrome were $32.6 \pm 5.6$ and $3.6 \pm 3.8$ and $27.0 \pm 4.3$ and $3.4 \pm 3.2$, respectively. In group 2, of 66 patients suspected as having HELLP syndrome, patients with complete and partial HELLP syndrome were 27 (40.9\%) and 39 (59.1\%), respectively. Of 39 patients with partial HELLP syndrome, the AST level was $>70$ IU/L in 12 patients, and AST and platelet count were $>70 \mathrm{IU} / \mathrm{L}$ and $<100,000 / \mu \mathrm{l}$ in 19 patients, respectively. The platelet count was $<100,000 / \mu \mathrm{l}$ in 5 patients. Parity and maternal age in patients with complete and partial HELLP syndrome were $2.9 \pm 1.6$ and $26.7 \pm 5.3$ and $2.4 \pm 1.6$ and $25.5 \pm 5.2$, respectively.

The rates of HELLP syndrome and eclampsia per 10,000 births in provinces are shown in Figure 1. When the incidence rate of HELLP syndrome and eclampsia were evaluated, the highest rate was seen in the Ardahan province (36 per 10,000 births). With 28 per 10,000 births, Artvin had the second-highest rate, and Erzurum, Kars, Ağrl, Bayburt, Muş, Bingöl, Erzincan, and Iğdır followed these provinces. 
Table 4. Comparison of parameters in subject populations

\begin{tabular}{|c|c|c|c|}
\hline Parameter & $\mid \begin{array}{c}\text { Group } 1 \text { (n:164) } \\
\text { (altitude >1500 m) }\end{array}$ & $\begin{array}{c}\text { Group } 2 \text { (n:78) } \\
\text { (altitude }<1500 \mathrm{~m})\end{array}$ & $\mathbf{p}$ \\
\hline Altitude (m) & $1040 \pm 287$ & $1736 \pm 122$ & $<0.01$ \\
\hline Age (years) & $28.6 \pm 7.3$ & $26.0 \pm 6.0$ & ns \\
\hline Gravidity (n) & $2.8 \pm 2.6$ & $2.7 \pm 2.6$ & ns \\
\hline Parity (n) & $1.6 \pm 2.0$ & $1.4 \pm 2.1$ & ns \\
\hline $\begin{array}{l}\text { Gestational age } \\
\text { (year) }\end{array}$ & $35.2 \pm 5.4$ & $34.0 \pm 5.1$ & ns \\
\hline MAP (mmHg) & $124.4 \pm 9.2$ & $118.4 \pm 8.6$ & ns \\
\hline $\mathrm{Hb}(\mathrm{g} / \mathrm{dl})$ & $12.9 \pm 2.2$ & $11.7 \pm 2.2$ & ns \\
\hline Thrombocyte $(/ \mu \mathrm{l})$ & $87,648 \pm 109.9$ & $96,347.0 \pm 107.0$ & $<0.05$ \\
\hline AST (IU/L) & $172.0 \pm 237.0$ & $130.5 \pm 150.9$ & $<0.01$ \\
\hline ALT (IU/L) & $286.0 \pm 91.0$ & $111.7 \pm 208.0$ & 0.01 \\
\hline LDH (IU/L) & $1208.0 \pm 755.0$ & $1366.0 \pm 1293.0$ & ns \\
\hline Uric acid (mg/dl) & $7.2 \pm 2.4$ & $6.7 \pm 2.7$ & ns \\
\hline Birth weight (g) & $2031 \pm 964$ & $2197 \pm 893$ & ns \\
\hline Cesarean rate (\%) & 57 & 56 & ns \\
\hline Fetal death (\%) & 38 & 17 & $<0.01$ \\
\hline
\end{tabular}

\section{Discussion}

Women living at high altitude have low uterine blood flow (21) and a high rate of IUGR (22). The maternal arterial system is normally insensitive to pressor agents in the circulation (23). However, in the case of a deterioration of insensitivity due to uteroplacental ischemia resulting from extreme vasoconstriction, hypoxia develops and this causes IUGR, maternal hypertension, and endothelial cell damage. Indeed, hypoxia deteriorates the arterial structure causing decreased sensitivity against vasoconstriction in pregnancy (24). These suggest that, because of increasing hypoxia, a higher rate of damaged placenta is the reason for increasing rates of preeclampsia at high altitudes.

Barometric pressure decreases with increasing altitude; pressure at sea level is $760 \mathrm{mmHg}$ and this decreases to $490 \mathrm{mmHg}$ at 4000 m altitude (25). Besides, arterial $\mathrm{PO}_{2}$ and hemoglobin $\mathrm{O}_{2}$ saturation, which are $95 \mathrm{mmHg}$ and $87 \%$ at sea level, decline to $50 \mathrm{mmHg}$ and 80\%, respectively, at high altitude (25). Hypoxia causes venous damages which is associated with low birth weight, thrombosis, and preeclampsia $(25,26)$. Kametas et al. (27) observed a 15\% decrease in plasma volume in pregnancy as altitude increased. The increased erythrocyte mass and decreased plasma volume cause hemoconcentration and hyperviscosity, and consequently a decrease in fetoplacental blood flow which could lead to IUGR and preeclampsia (28).

Sibai et al. (29) reported that mean maternal age was 27.4 26.7 in their study. In the present study, in patients with HELLP syn-

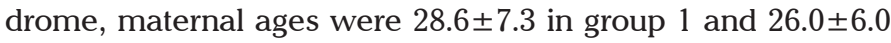
in group 2. In this study, maternal age, gravidity, parity, and ges- tational age were insignificant, but hemoglobin levels increased with altitude (12.9 vs. $11.7 \mathrm{~g} / \mathrm{L}$ in Group 1 and 2; p<0.01). Palmer et al. (12) revealed that the incidence of preeclampsia at $3100 \mathrm{~m}$ and $1260 \mathrm{~m}$ was $16 \%$ and $3 \%$, respectively, and it increased with increasing altitude. In the present study, overall preeclampsia and eclampsia incidence rate was $7.2 \%(n=582)$ during the last 5 years, which is in agreement with the literature $(6,7)$. Taking patients with HELLP syndrome and eclampsia into consideration, we aimed to determine the present situation in the Eastern Anatolian region. With 209 cases in the past 5 years, HELLP syndrome occurred in $2.6 \%$ of total births and $36 \%$ of preeclamptic patients in our clinic. It was reported that HELLP syndrome progressed in $4-12 \%$ of preeclamptic patients (30). In the present study, the rates of HELLP syndrome are 3-9 times higher than literature findings. This could be due to the fact that preeclamptic patients seek health care only when their health status is complicated by conditions such as HELLP syndrome and eclampsia.

Total birth number and the number of cases of HELLP syndrome and eclampsia in the last 5 years were 114,899 and 164, respectively, in places higher than $1500 \mathrm{~m}$ altitude. The rate of HELLP syndrome and eclampsia was $0.14 \%$, in places lower than $500 \mathrm{~m}$ altitude, the total birth number was 81,374 , and the rate of cases of HELLP syndrome and eclampsia was $0.096 \%$ $(p<0.01)$. When the rate for HELLP syndrome and eclampsia is combined, the rate in places higher than $1500 \mathrm{~m}$ altitude was much higher than in places below $1500 \mathrm{~m}$ altitude. The highest rate was seen in Ardahan (36 cases per 10,000 births), and the lowest rate was seen in Iğdır (9.8 cases per 10,000 births).

When HELLP syndrome and eclampsia rates were considered, it could be clearly seen that provinces with similar altitudes have similar rates; for example, 22.9 in Erzurum (1864 m.), 18.8 in Kars (1875 m.) and Ağrı (1732 m.), and 18.0 in Bayburt (1684 m.). Although the Ardahan province has a similar altitude (1929 m.), the rate in this province was 36. Likewise, Artvin is located at low altitude, the rate, 28 per 10,000 births, was much higher than the group mean (11.5). This could be related to other nutritional and environmental factors that could contribute to preeclampsia. On the other hand, with 9.9 and 10 cases per 10.000 births, Iğdır and Erzincan in group 2 (<1500 m altitude) had the lowest rates among the other provinces.

Liver impairment could result in serious problems in HELLP syndrome and plays a vital role in mortality; it is the cause of 1 out of 6 maternal mortalities (4). Elevations in enzyme levels, especially AST, indicate liver impairment. Leakage of enzymes from cell membranes to the blood is the reason for high enzyme levels in HELLP syndrome. With 172.0 237.0 IU/L (721061), AST levels in group 1 were significantly higher $(\mathrm{p}<0.01)$ than those in group 2, 130.5 $\pm 150.9 \mathrm{IU} / \mathrm{L}$ (82-1064). It could be inferred that, with increasing altitude, a higher rate of HELLP syndrome was seen.

With $166 \mathrm{~g}$ difference, fetal weight was found to be lower in group 1 than group $2(2031 \pm 964 \mathrm{~g}$ in group 1 and $2197 \pm 893$ in group 2). Palmer et al. (12) reported that with $285 \mathrm{~g}$ difference, people living at $3100 \mathrm{~m}$ altitude had a lower fetal weight than those at $1260 \mathrm{~m}$ altitude. At 38\%, (62 cases), the fetal death rate in group 1 was higher than that in group 2 with $18 \%$ (14 
cases), but no studies of high fetal death rates at high altitude could be found in the literature. However, it is clear that, in our study, death rate of preeclamptic babies at high altitude is about twice that at lower altitude. The eclampsia rate is about 1 in 2000 pregnancies in developed countries (31), whereas this rate was determined to be 1 in 100-1700 pregnancies in developing countries, and eclampsia is still the reason for $10 \%$ of maternal mortalities (18). Chen et al. (32) reported that this rate in Singapore is 6.7 per 10,000 pregnancies. With 45 cases, our eclampsia rate is similar to rates found in that study. The etiological relation of HELLP syndrome and eclampsia to preeclampsia is not well known. Moreover, it was previously thought that abnormal trophoblast invasion of uterine arteries, immunological intolerance between fetoplacental and maternal tissue, maladaptation to cardiovascular changes of pregnancy, dietary deficiency, and genetic abnormalities could affect these illnesses (33).

Our study demonstrated a greater incidence of eclampsia accompanied by complete and/or incomplete HELLP syndrome among women living at high altitude (>1500 m). However, our results have certain limitations that probably contribute to this illness, such as economical and nutritional status, diagnosis time relative to disease onset, and interactions among these and other unmentioned causes.

\section{Conflict of interest}

None declared.

\section{References}

1. White MM, Mc Cullough RE, Dyckes R, Robertson AD, Moore LG. Chronic hypoxia, regnancy, and endothelium-mediated relaxation in guinea pig uterine and thoracic arteries. Am J Physiol Heart Circ Physiol 2000; 278: 2069-75.

2. Weiner CP, Martinez E, Chestnut DH, Ghodsi A. Effect of pregnancy on uterine and carotid artery response to norepinephrine, epinephrine and phenylephrine in vessels with documented functional endothelium. Am J Obstet Gynecol 1989: 161; 1605-10.

3. White MM, Mc Cullough RE, Dyckes R, Robertson AD, Moore LG. Effects of pregnancy and chronic hypoxia on contractile responsiveness to alphal-adrenergic stimulation. J Appl Physiol 1998; 85: 2322-9.

4. Magann EF, Martin J N J r. Twelve steps to optimal management of HELLP syndrome. Clin Obstet Gynecol 1999; 42: 532-50. [CrossRef]

5. Sibai BM. Maternal and uteroplacental hemodynamics for the classification and prediction of preeclampsia. Hypertension 2008; 52: 805-6. [CrossRef]

6. Hauth J C, Ewell MG, Levine RJ, Esterlit JR, Sibai B, Curet LB, Catalano PM, Morris CD. Pregnancy outcomes in healthy nulliparas who developed hypertension. Obstet Gynecol 2000; 95: 24-8. [CrossRef]

7. Knuist M, Bonsel G] , Zondervan HA, Treffers PE. Intensification of fetal and maternal surveillance in pregnant women with hypertensive disorders. IntJ Gynaecol Obstet 1998; 61: 127-33. [CrossRef]

8. Sibai BM, Hauth J , Caritis S, Lindheimer MD, Mac Pherson C, Klebanoff $M$ et al. Hypertensive disorders in twin versus singleton gestations. National Institute of Child Health and Human Development Network of Maternal-Fetal Medicine Units. Am J Obstet Gynecol. 2000; 182: 938-42. [CrossRef]

9. Jeffcoate TN. Pre-eclampsia and eclampsia: the disease of theories. Proc R Soc Med 1966; 59: 397-404.

10. Aksoy H, Kumtepe Y, Akcay F, Yildirim AK. Correlation of P-selectin and lipoprotein(a), and other lipid parameters in preeclampsia. Clin Exp Med 2002; 2: 39-43. [CrossRef]
11. Arkel YS, Ku DH. Thrombophilia and pregnancy: review of the literature and some original data. Clin Appl Thromb Hemost 2001; 7: 259-68. [CrossRef]

12. Palmer SK, Moore LG, Young D, Cregger B, Berman JC, Zamudio S. Altered blood pressure course during normal pregnancy and increased preeclampsia at high altitude (3100 meters) in Colorado. Am J Obstet Gynecol 1999; 180: 1161-8. [CrossRef]

13. Moore LG, Hershey DW, Jahnigen D, Bowes W Jr. The incidence of pregnancy-induced hypertension is increased among Colorado residents at high altitude. Am J Obstet Gynecol 1982; 144: 423-9.

14. Rockwell LC, Vargas E, Moore LG. Human physiological adaptation to pregnancy: inter- and intraspecific perspectives. Am J Human Biol 2003; 15: 330-41. [CrossRef]

15. Moore LG, Niermeyer S, Zamudio S. Human adaptation to high altitude: regional and life-cycle perspectives. Am J Phys Anthropol 1998; 27: 25-64. [CrossRef]

16. Weinstein, L. Syndrome of hemolysis, elevated liver enzymes, and low platelet count: a severe consequence of hypertension in pregnancy. Am J Obstet Gynecol 1982; 142: 159-67.

17. Sibai BM. The HELLP syndrome (hemolysis, elevated liver enzymes, and low platelets): much ado about nothing? Am J Obstet Gynecol 1990; 162: 311-6.

18. Duley L. Maternal mortality associated with hypertensive disorders of pregnancy in Africa, Asia, Latin America and the Caribbean. Br J Obstet Gynaecol 1992; 99: 547-53. [CrossRef]

19. Haram K, Svendsen E, Abildgaard U. The HELLP syndrome: Clinical issues and management. A review. BMC Pregnancy Childbirth 2009; 9: 8. [CrossRef]

20. Davey DA, Mac Gillivray I. The classification and definition of the hypertensive disorders of pregnancy. Am J Obstet Gynecol 1998; 158: 892-8.

21. Zamudio S, Palmer SK, Dahms TE, Berman JC, Young DA, Moore LG. Alterations in uteroplacental blood flow precede hypertension in preeclampsia at high altitude. J Appl Physiol 1995; 79: 15-22.

22. Yip R. Altitude and birth weight. J Pediatr 1987; 111: 869-76. [CrossRef]

23. Zamudio S, Torricos T, Fik E, Oyala M, Echalar L, Pullockaran J et al. Hypoglycemia and the origin of hypoxia-induced reduction in human fetal growth. PLoS One. 2010; 5: 8551. [CrossRef]

24. Genbacev O, Zhou Y, Ludlow JW, Fisher SJ. Regulation of human placental development by oxygen tension. Science 1997; 277: 1669-72. [CrossRef]

25. Andrew J. Pollard, David R. Murdoch. The high altitude medicine handbook. British Library. 3rd Edition, 2003.

26. J ensen GM, Moore LG. The effect of high altitude and other risk factors on birth weight: independent or interactive effects? Am J Public Health 1997; 87: 1003-7. [CrossRef]

27. Kametas N, Mc Auliffe F, Krampl E, Sherwood R, Nicolaides KH. Maternal electrolyte and liver function changes during pregnancy at high altitude. Clin Chim Acta 2003; 328: 21-9. [CrossRef]

28. Steegers EA, von Dadelszen P, Duvekot JJ, Pijnenborg R. Pre-eclampsia. Lancet. 2010; 376: 631-44.

29. Sibai BM, Ramadan MK, Usta I, Salama M, Mercer BM, Friedman SA. Maternal morbidity and mortality in 442 pregnancies with hemolysis, elevated liver enzymes, and low platelets (HELLP syndrome). Am J Obstet Gynecol. 1993; 169: 1000-6.

30. Sibai BM, Taslimi MM, El-Nazer A, Amon E, Mabie BC, Ryan GM. Maternal-perinatal outcome associated with the syndrome of hemolysis, elevated liver enzymes, and low platelets in severe preeclampsia-eclampsia. Am J Obstet Gynecol. 1986; 155: 501-9.

31. Douglas KA, Redman CW. Eclampsia in the United Kingdom. BMJ . 1994; 309: 1395-400.

32. Chen CY, Kwek K, Tan KH, Yeo GS. Our experience with eclampsia in Singapore. Singapore Med J. 2003; 44: 88-93.

33. Sibai BM. Diagnosis and management of gestational hypertension and preeclampsia. Obstet Gynecol. 2003; 102: 181-92. [CrossRef] 